\title{
Rainfall Thresholds for Landslide Prediction in Loano Subdistrict, Purworejo District Central Java Province
}

\author{
Farma Dyva Ferardi¹,3, Wahyu Wilopo ${ }^{1,3}$, and Teuku Faisal Fathani ${ }^{2,3}$ \\ ${ }^{1}$ Department of Geological Engineering, Faculty of Engineering, Gadjah Mada University, Yogyakarta, Indonesia \\ ${ }^{2}$ Civil and Environmental Engineering Department, Faculty of Engineering , Universitas Gadjah Mada, Yogyakarta, \\ Indonesia \\ ${ }^{3}$ GAMA-InaTEK, Centre of Excellence of Technological Innovation for Disaster Mitigation, Universitas Gadjah Mada \\ Yogyakarta, Indonesia
}

\begin{abstract}
Purworejo Districtis a district with high disaster risk index in Indonesia, especially landslide. The main factor that triggers the landslide is rainfall. However, there has been no comprehensive research on the intensity of rain that triggered the landslide in Purworejo District, especially in the Sub district of Loano. Huge landslide occurred in Loano Sub district at 2016, causing 46 deaths and damages in several houses. Therefore, it is necessary to study the prediction of landslide based on rainfall data and geological conditions of Loano Sub district, Purworejo District. The objective of this research is to analyze the mechanism of landslide, to analyze the rainfall that triggers the landslide and to estimate the intensity of rain that can triggers the landslide. The research method is collecting historical data of landslides in Purworejo District along with rainfall data, geological observation that includes the condition of lithology, geomorphology and hydrogeology, undisturbed soil sampling in Loano Sub district. The prediction of landslide uses empirical methods which were then simulated by Geostudio 2012 Software. The results show that the type of landslide is sliding, the main control factor is the steep slope and the thickness of the soil. The rainfall threshold triggering landslide are as follows for lithology andesite breccia $I=81.782 D^{-1.197}$, sandy clay $I=92.579 D^{-0.13}$, and andesite intrusion $I=145.32 D^{-0.338}$.
\end{abstract}

Keywords: Landslide · Prediction · Rainfall thresholds · Loano Subdistrict · Central Java.

\section{INTRODUCTION}

Purworejo District is ranked $19^{\text {th }}$ out of 496 districts and cities throughout Indonesia with a disaster risk index score of 215 or high category (BNPB, 2013). In 2016, a large-scale of landslide disaster occurred in Caok village, Karangrejo village, Loano sub-district claimed 46 casualties, 15 missing people and dozens of damaged houses (Widiastutik \& Buchori, 2018).The rainfall and geological condition are the main factors causing the landslide (Cruden et al., 1996; Varnes, 1978; Varnes, 1984). Rainfall intensity

\footnotetext{
${ }^{*}$ Corresponding author: F.D. FERARDI, Department of Geological Engineering, Gadjah Mada University. Jl. Grafika 2 Yogyakarta, Indonesia. E-mail: farmadyva123@gmail.com
}

as a trigger for landslide varies depending on the geological conditions of each region (Karnawati; 2005). There are several ways to analyze rainfall threshold, one of them is empirical methods (Guzzetti et al., 2005).An empirical threshold is composed by geological conditionssuch as; soil moisture, thickness of soil, and hydrology. When rainfall reaches or exceeds the threshold, it will trigger landslide (Reichenbach et al., 1998; Cepeda et al., 2010). By understanding the rainfall thresholds, the casualties due to landslide can be reduced and as an illustration for the relevant agencies in performing the most appropriate mitigation actions (Peruccacci et al., 2017).The application of rainfall thresholds is then developed as early warning system 
for landslide (Aleotti, 2004; Huang et al., 2015; Luca et al., 2017). Therefore, it is necessary to study the prediction of landslide based on the analysis of rainfall data and geological conditions, especially in Loano District generally in Purworejo District.

This research is aim to: (i) Evaluate the mechanism of landslide, (ii) Analyze the rainfall that triggers the landslide, (iii) Estimate the intensity of rain that triggers the occurence of landslide.

\section{RESEARCH METHODS}

There are 2 sources of data used in this study; primary data and secondary data. Primary data include geological data (morphology, geological structure, hydrology and hydrogeology, lithology, and land use). Secondary data include regional geological data, history of landslide in 2008-2018, and daily rainfall data of 2008-2018. The rainfall data was prepared bythe Irrigation Department, Public Works Agency of Purworejo District. The history of landslide was prepared by the Disaster Management Agency Purworejo District, Ministry of Health,and local newspaper.

The research was conducted in 4 stages method, starting from the preparation phase covering problem formulation, literature study, and secondary data gathering including daily rainfall data of 2008-2018 and history of landslide of 2008-2018. The second stage is fieldwork and laboratory analysis. This stage includes collecting engineering geology aspects such as morphology, lithology, undisturbed soil sampling, geological structure, depth of groundwater level, land use and observation on the location of landslide. In addition, it also includes testing undisturbed soil sample in the laboratory (ASTM, 2000). The third stage is data analysis of geological maps, geomorphology, rainfall thresholds in each geological condition, and slope stability analysis. The geological condition is represented by the lithological unit in Loano District. Therefore, each geological condition has each rainfall threshold. Then, the final stage is the conclusions and advice from research.

\section{DATA REPORTING}

\subsection{Geomorphology of the research area}

The geomorphology zone of research area is based on morphography aspect or slope value by Karnawati (2005). The geomorphology of the research area is divided into 4 zones, namely; Plain $\left(0-10^{\circ}\right)$, Low Slope Zone $\left(10-20^{\circ}\right)$, Medium Slope Zone (20-40 $)$, and High Density Zone $\left(>40^{\circ}\right)$. The study area is dominated by medium slope zones and the location of the landslide is mostly found in the medium slope zone and in the high slope zone.

\subsection{Geological of research area}

The geological mapping in the study area resulted in 3 geological units, from the oldest until the youngest, namely andesite breccia units, andesite intrusion, and alluvial deposit (sandy clay deposit). In this study area,the geological structures are normal fault and shear joint. The normal fault is found in Glagah River while the direction of the shear joint isrelatively northwest-southeast. From the remote sensing analyzis, a dextral and sinistral fault. The geological map of study area is shown in Figure 1.

\subsection{Rainfall of research area}

The main triggering factor of landslide especially in Indonesia is due to high rainfall (Karnawati, 2005). Rain can reduce the tension between rock pores, weathering rocks so that the value of rock cohesion decreases (Hardiyatmo, 2012). To predict landslide, needs daily rainfall data within a period of 10 years from 2008 to 2018.

Statistics of rain events in the study area indicate that the rain always drops in 4 consecutive months in November-April. Peak of the rainy season occurs in December and January. Anomalies occur in 2014 and 2016 where in that year the peak of the rainy season occurred in June. The data is coming from Irrigation Department, Public Work Services, Purworejo District from 2008-2018. Figure 2 shows the rain intensity graph for 10 years.

\subsection{Characteristics of soil mechanics}

Soil technical parameters were obtained from laboratory tests. This test aims to determine the soil properties used as a parameter of slope stability and the landslide mechanism that occurs. 


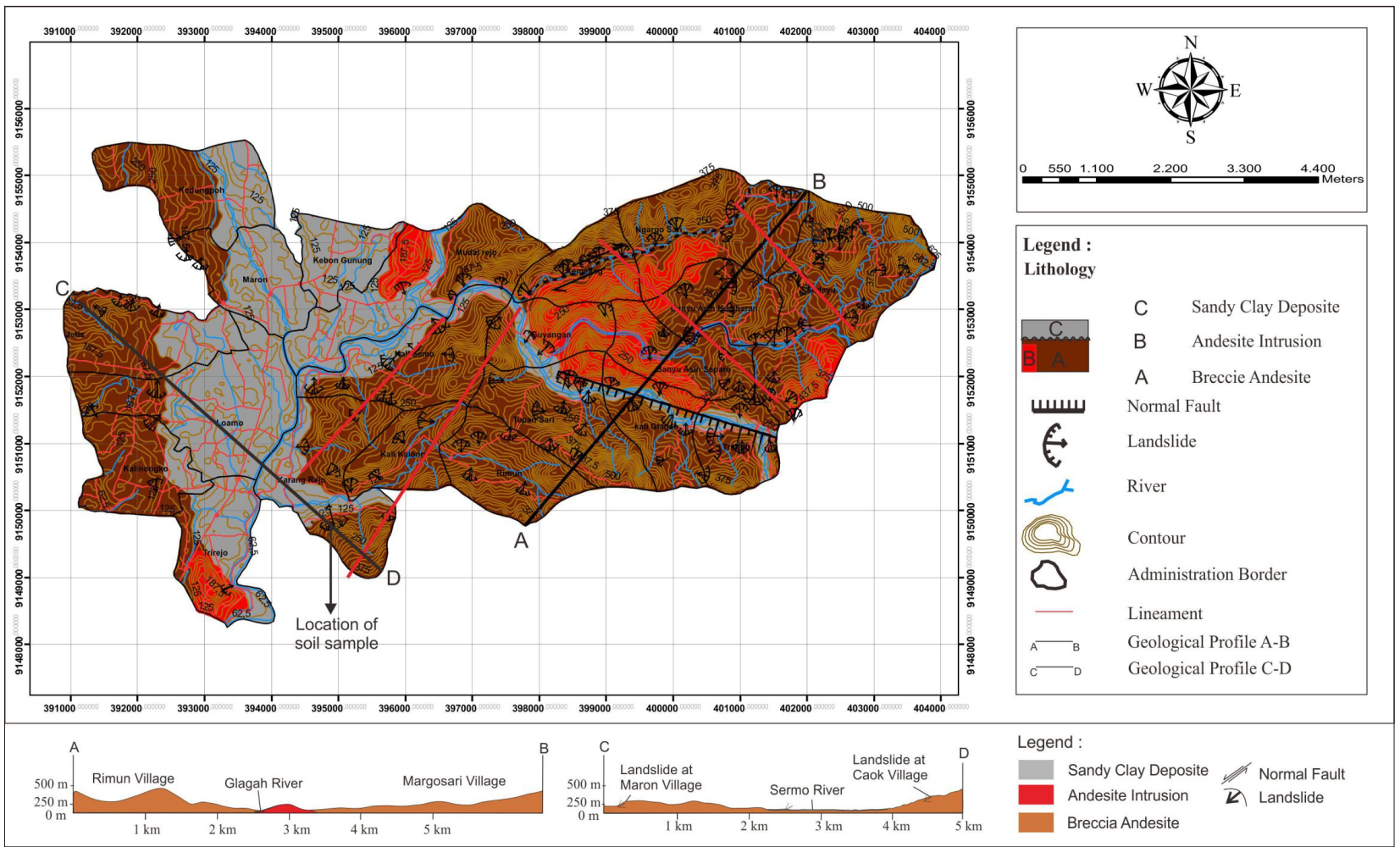

Figure 1. Geological map of research area.

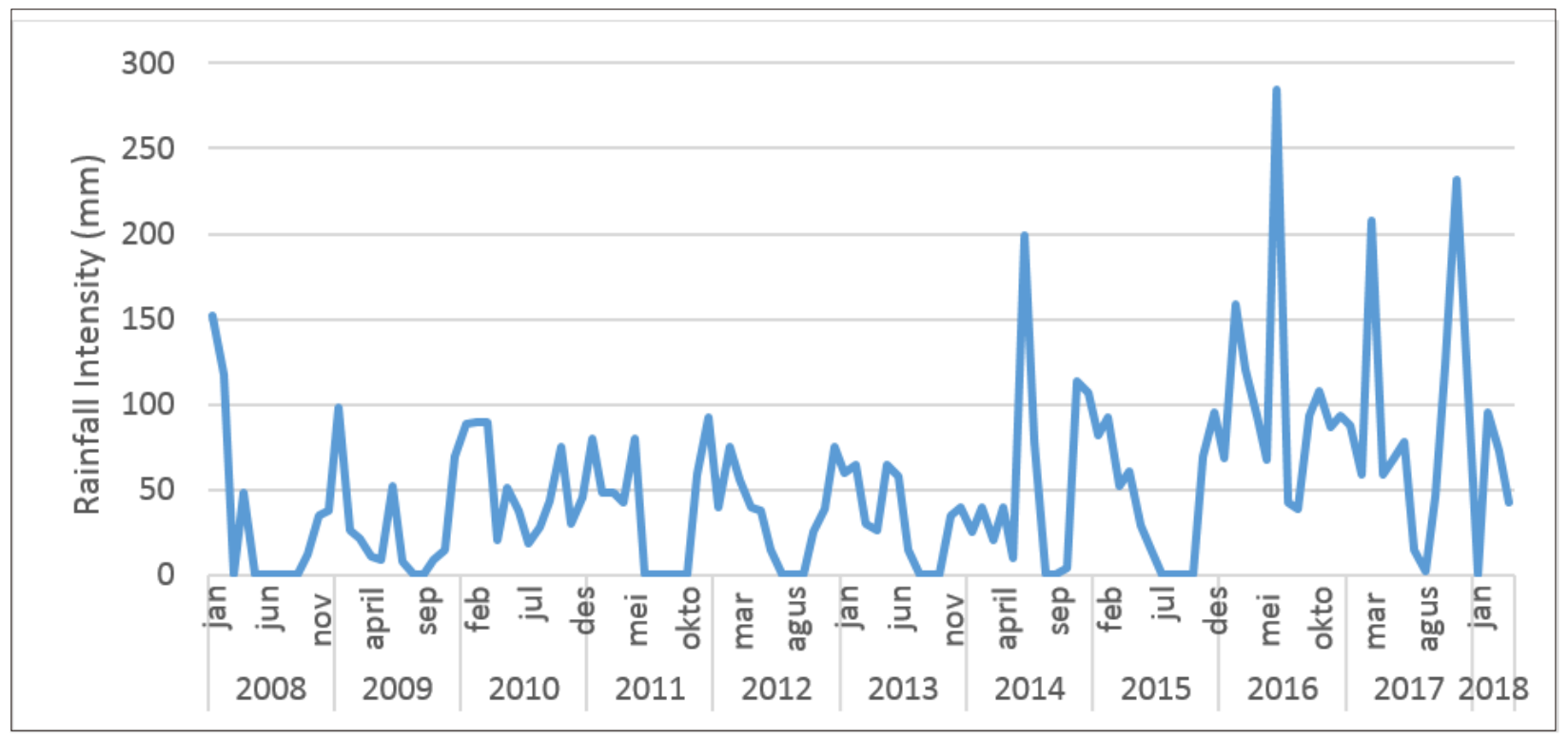

Figure 2. Graphic of rainfall intensity in study area from 2008-2018. 
Soil sampling is focused on Caok Village which is the most vulnerable area of landslide and is considered to represent the research location. The location of soil sampling is shown in Figure 1. An original rock from soil samples isin the form of andesite breccia that has undergone intensive weathering. The tested parameters include grain size distribution, specific gravity, water content, atterberg limit, and triaxial test.Table 1shows the result of undisturbed soil sample testing in each parameter.

\section{ANALYSIS}

\subsection{Landslide mechanism}

In the research area, there is a geological structure, shear joint, with the relative direction of the northwest, $\mathrm{N} 353^{\circ} \mathrm{E}$ and $\mathrm{N} 302^{\circ} \mathrm{E}$. At this location,is indicated the present of normal fault due to sudennly change in the topograpich elevation.

The observed landslide is rotational slide with slides in the form of curved curves or horseshoes. This type of landslide often occurs on steep slopes $\left(>40^{\circ}\right)$. Landslide is controlled by a steep slope of $43^{\circ}$ so that the gravitational force produced when the soil experiences movement is even greater. The constituent rocks, andesite breccia, which are volcanic products, are susceptible to weathering due to the dominance of the feldspar mineral content. Feldspar is easily weathered which makes the andesite breccia altered into a thick layer of soil.

The presence of shear joint becomes a discontinuity for rocks so that rainwater can enter and interact with feldspar minerals. This mineral feldspar is susceptible to alter into clay mineral when interacting with rainwater. This clay mineral can be a slip surface of landslide. On the observed location, the slip surface is in the form of lapsed andesite breccia that has been altered into clay soil size with direction of $\mathrm{N} 43^{\circ} \mathrm{E}$ and the direction of landslide is $\mathrm{N} 55^{\circ} \mathrm{E}$. Both the direction of avalanche and the slope of the slip surface have the same relative direction that is northeast, thus increasing the occurrence of large-scale landslide. Figure 3 shows the morphological appearance of landslide at the study site.

\subsection{Rainfall thresholds and lithological unit}

Rainfall intensity that can trigger landslide in each region is different. This difference is certainly caused by the geological conditions, especially rock types, compactness, and weathering rates. Therefore, each geological condition, represented by lithological unit, will have different rainfall threshold.

Collecting the landslide history data is an important step that must be carried out in this research. The landslide history data have information about rainfall intensity and duration when the landslide occurs, type of landslide, and type of lithological unit. In addition, the value of rainfall threshold is obtained by plotting rainfall intensity and rainfall duration.

In this research, there are several lithological units thatare sandy clay, andesite intrusion, and andesite breccia (Rahardjo et al., 1995). The plotting of rainfall threshold is done on each lithological unit.

\subsubsection{Alluvium deposit (sandy clay)}

The value of rainfall threshold is obtained by plotting the rainfall intensity and duration of landslide that occurs on alluvium deposit. By using this method, the rainfall threshold values is represented by equation $I=92.697 D^{-0.13}$. The value of $I$ means maximum rainfall intensity while $D$ means the duration of rainfall calculated in number of days. This rainfall threshold value is very suitable to be used in the development of early warning systems with geological conditions in the form of alluvium deposits. Figure 4 shows the rainfall threshold curve in the geological condition of the clay deposits. Landslides that occur in geological conditions in the form of avalanches on the cliffs is due to increased flow of river currents.

When there is rainfall with the intensity of $85 \mathrm{~mm}$ /day with the duration of 1 day or above the curve line, then it is predicted that a landslide will occur. When there is rainfall with an intensity of $60 \mathrm{~mm} /$ day for 4 days, it is predicted that a landslide will occur. Meanwhile, when it is exactly at the line of the rainfall threshold, the soil is predicted to be in critical condition.

\subsubsection{Andesite intrusion}

When the geological conditions are in andesite intrusion, the rainfall threshold values is repre- 


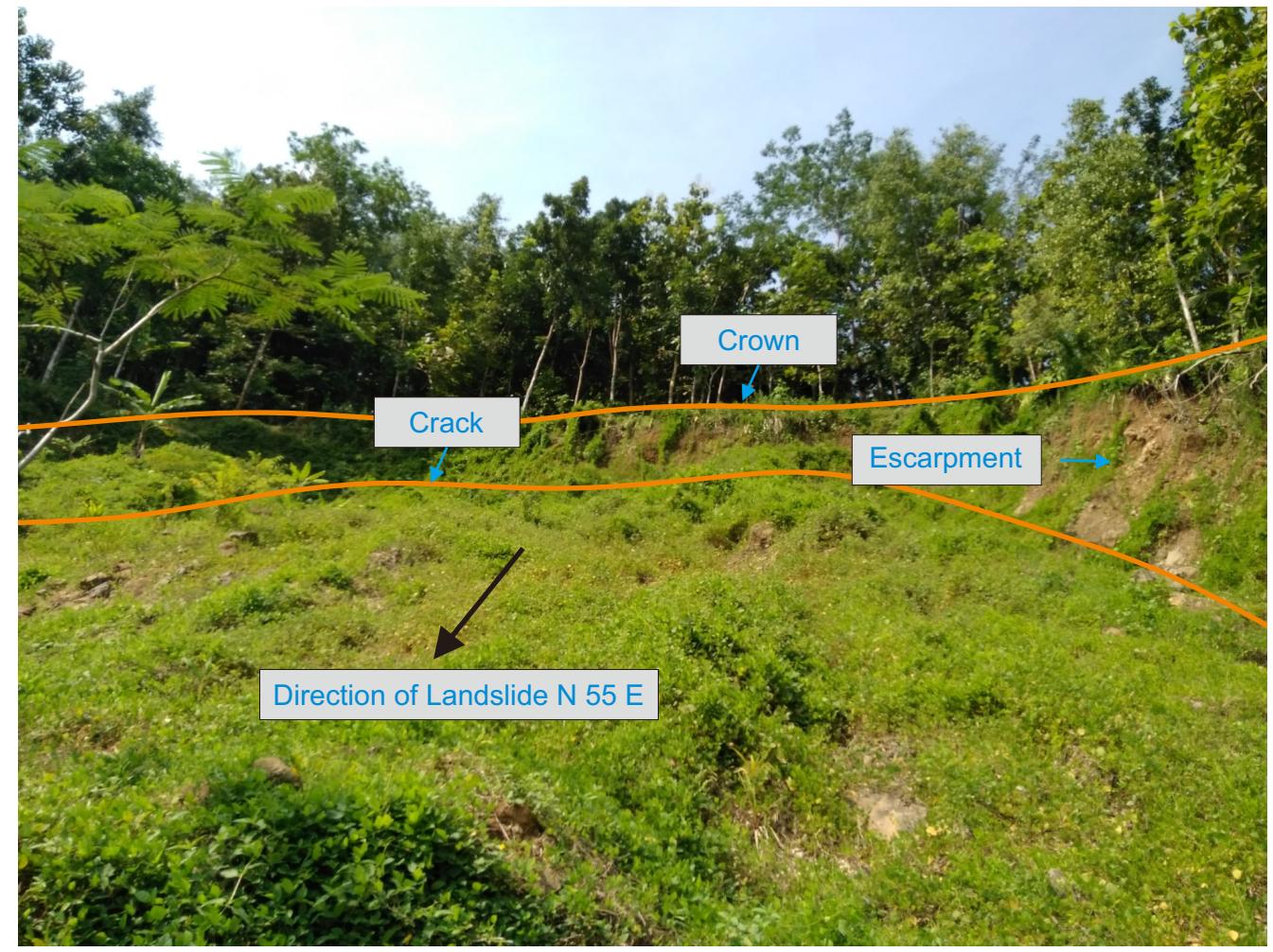

Figure 3. Landslide morphology on study area, Dusun Caok, Karang Rejo.

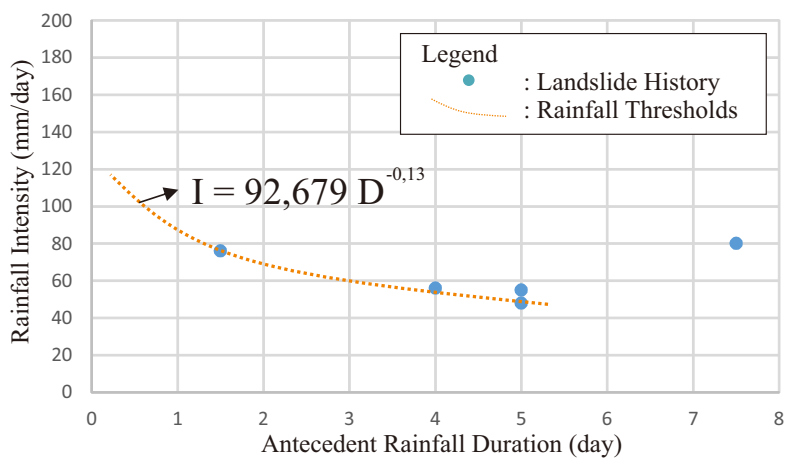

Figure 4. Rainfall thresholds curve for sandy clay.

sented by the equation $I=145.32 D^{-0.338}$. The value of $I$ means maximum rainfall intensity while $D$ means the duration of rain calculated in number of days. This rainfall threshold value is very suitable for the development of early warning system in Purworejo District. Figure 5 shows the rainfall threshold curve in the geological conditions of andesite intrusion. Landslides that occur in this geological unit issliding type. Landslides occur in weathered andesite.

When there is rainfall with intensity of $100 \mathrm{~mm} /$ day with the duration of rain 1 day or above the curve line then a landslide will occur. When there is rainfall with intensity of $70 \mathrm{~mm} /$ day for 2 days, then a landslide will

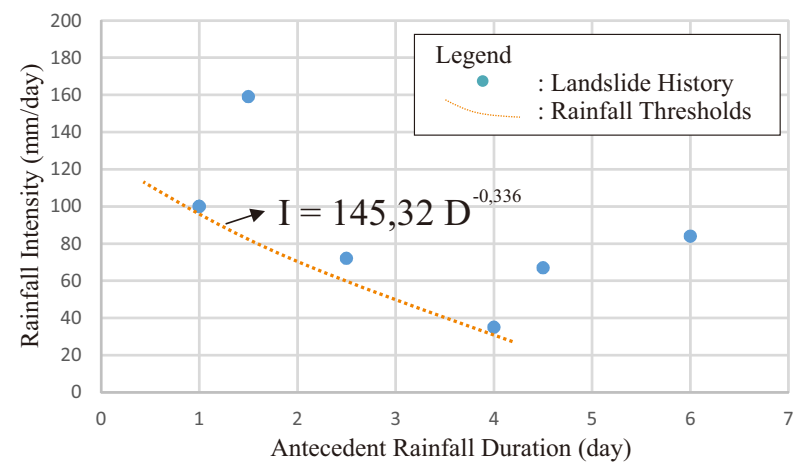

Figure 5. Rainfall thresholds curve for andesite intrusion.

occur. Moreover, if it is exactly at the line of the rainfall threshold, the land is predicted to be in critical condition. The intensity of rain triggering landslide for this geological condition is greater than other geological conditions.This is because andesite lithology has the highest and freshest compactness compared to other lithologyin the study area.

\subsubsection{Andesite breccia}

The rainfall threshold values of andesite brecciais represented by the equation $I=$ $81.782 D^{-1.197}$. Value $I$ means the maximum rain intensity whereas $D$ means the duration 


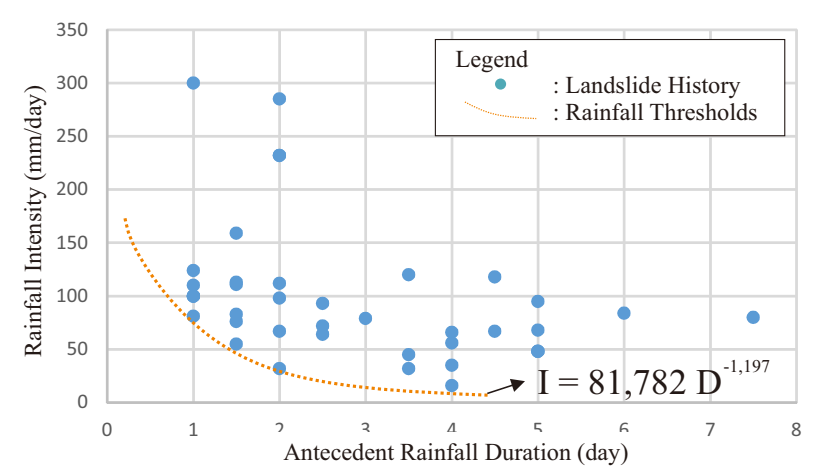

Figure 6. Rainfall thresholds curve for andesite breccia.

of rain calculated in number of days. This rainfall threshold value is very suitable for the development of the early warning system in Purworejo District. Figure 6 shows the rainfall threshold curve in the geological conditions of the andesite breccia.

When there is rainfall with intensity of $80 \mathrm{~mm}$ /day with the duration of rain 1 day or above the curve line then a landslide will occur. When there is rainfall with intensity of $30 \mathrm{~mm} /$ day for 2 days hence predicted landslide. Meanwhile, when it is still in the rainfall threshold curve, then the soil is predicted to be in a critical condition.

\subsection{Landslide prediction}

The prediction of landslide occurrences in this study is related with rainfall thresholds and slope stability analysis. In this research, the analysis of slope stability and prediction of landslide occurrence using Geostudio 2012 software aid that is Seep/W and Slope/W. The Seep/W software is used to determine the infiltration of rainwater that enters the soil during rainfall under certain conditions and its relation to groundwater rise. Slope/W is used for the slope stability analysis by considering the condition of the ground water level. The Parameter input in Geostudio 2012 is water content, cohesion, angle of friction, bulk density, and dry density (Table 1).

This simulation is performed on soil samples from intensive weathering of andesite breccia on Table 1 noted as S2. The location of samples had experienced landslides in 2016. However, the sampling is carried out on soil that has never experienced landslides. The Simulation was performed only on lithology an- desite breccia which represents all of lithological units and considered as a verification of rainfall thresholds in each lithological unit. The rainfall thresholds of andesite breccia is represented by the equation $I=81.782 D^{-1.197}$ where $\mathrm{I}$ is intensity in $\mathrm{mm}$ and $\mathrm{D}$ is time in day.

The prediction of the landslide occurrence in this study includes 4 simulations. The first simulation was performed in a normal condition where there was no rise in ground water level, no rain, and no decrease in soil mechanical properties, the value of cohesion, and friction angle. The simulation, which is the initial condition of slope, shows the safety factor is 1.442 (Figure 7A). This safety factor indicates the slope is stable or safe (Bowles, 1984).

In the second simulation, the rainfall was below the rainfall threshold,which was $50 \mathrm{~mm} /$ day with 1 day rain duration. In this simulation therewas an increase in ground water level, a decrease in cohesion values, and an increase in weight of slopes. The rainfall input in Slope/W was still under the rainfall thresholds. The second simulation shows the safety factor is 1.371 (Figure 7B). This safety factor indicates the slope is still stable or safe (Bowles, 1984).

The third simulation waswhere rainfall was exactly on the rainfall threshold, which was $50 \mathrm{~mm} /$ day with 1.5 days duration of rain. In this simulation, there was an increase in ground water level compared to the initial condition and there was a decrease in cohesion value and increase weight of slope. When the rainfall input in Slope/W reachesthe rainfall thresholds, the safety factor is 1.171 (Figure 7C) which is the slope is critically to move (Bowles, 1984).

The fourth simulation was when the rainfallwas above the rainfall threshold, which $200 \mathrm{~mm} /$ day with 1 day rain duration. In this simulation, there was a significant rise in groundwater level compared to the initial condition, the decrease of soil cohesion value and the increase weight of slope. When the rainfall exceeds the rainfall thresholds, the safety factor is 0.874 (Figure 7D). This safety factor indicates that the slope is unstable or critical. Figure 7 shows the illustrations of each simulation. 
Table 1. The result of undisturbed soil sample testing in each parameter.

\begin{tabular}{llccccc}
\hline \multirow{2}{*}{ Testing } & \multirow{2}{*}{ Parameter } & \multirow{2}{*}{ Notation } & \multirow{2}{*}{ Unit } & \multicolumn{3}{c}{ Sample of Andesite Breccia } \\
& & & & S2 & S4 & S7 \\
\hline Water Content & Water content & $w$ & $\%$ & 45145 & 39063 & 46041 \\
\hline \multirow{2}{*}{ Volumetric Weight } & Bulk density & $\gamma_{b}$ & gram $/ \mathrm{cm}^{3}$ & 2.43 & 1905 & 21.39 \\
& Dry density & $\gamma_{d}$ & $\mathrm{gram} / \mathrm{cm}^{3}$ & 1.67 & 1.37 & 14.65 \\
\hline \multirow{2}{*}{ Specific Gravity } & Specific gravity & $G_{s}$ & & 2654 & 2656 & 2677 \\
\hline \multirow{3}{*}{ Atterberg Limit } & Liquid limit & $L L$ & $\%$ & 43.96 & 43.65 & 43.36 \\
& Plastic limit & $P L$ & $\%$ & 30.14 & 30.92 & 37.84 \\
& Plasticity Index & $P I$ & $\%$ & 13.82 & 12.73 & 5.53 \\
& Liquidity Index & $L I$ & & 1.09 & 0.64 & 1.48 \\
\hline \multirow{3}{*}{ Grain Size } & Percentage of gravel & & $\%$ & 0 & 0 & 0 \\
& Percentage of sand & & $\%$ & 9.7 & 10.01 & 23.01 \\
& Percentage of silt/clay & & $\%$ & 90.3 & 89.99 & 76.99 \\
\hline \multirow{2}{*}{ Triaxial CU } & Angle of internal friction & $\varphi$ & $\circ$ & 24 & 6 & 13 \\
& Cohesion & $c$ & $\mathrm{kPa}$ & 20885 & 60.12 & 17.45 \\
\hline
\end{tabular}

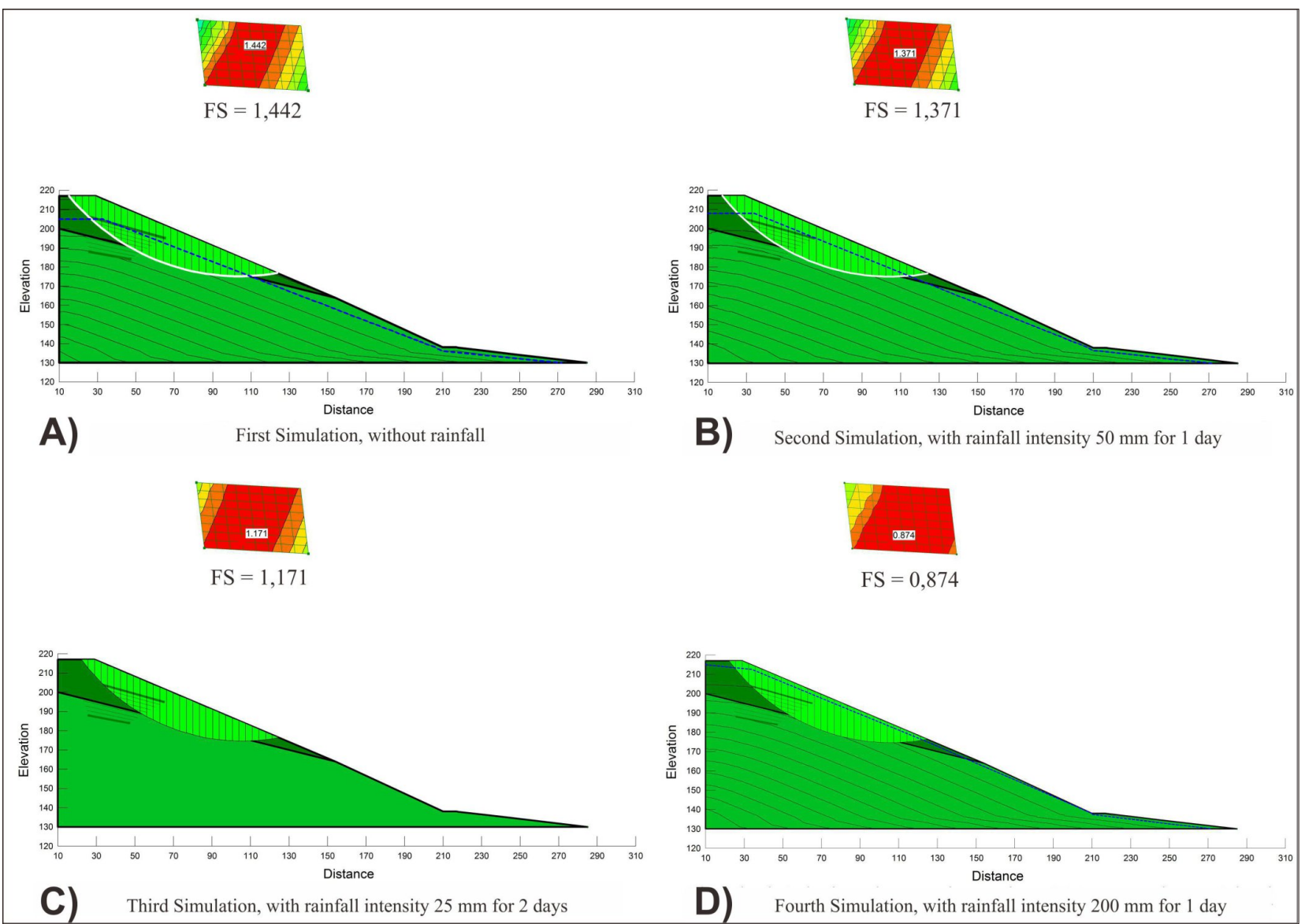

Figure 7. The illustration of landslide by each rainfall thresholds. 


\section{CONCLUSION}

Based on the results of the research and the data analysis, several conclusions can be drawn. The mechanism of landslides that occurs is dominated by the type of sliding type, namely rotational sliding or slump.Landslides will occur along the discontinuity plane. The main controlling factors arethe steep slope and the thick soil. The triggering factor is high rainfall intensity.

Rainfall threshold values that trigger landslides vary in each type of lithology. The rainfall threshold valuefor the sandy caly deposit represented by the equation $I=92.679 D^{-0.13}$. The rainfall threshold values fo the andesite intrusion represented by the equation $I=$ $145.32 D^{-0.338}$, and the rainfall threshold for theandesite breccia represented by the equation $I=81.782 D^{-1.197}$. While $\mathrm{I}$ is the rain intensity ( $\mathrm{mm} /$ day) and $\mathrm{D}$ is the duration of rain (days). Landslides will occur with rainfall intensity of more than $95 \mathrm{~mm} /$ day for sandy clay deposit. However for andesite intrusion and andesite breccia are more than $145 \mathrm{~mm} /$ day and more than $80 \mathrm{~mm} /$ day, respectively.

\section{ACKNOWLEDGEMENTS}

The authors would like to thank to Geological Engineering Department UGM for supporting all expense inthis research.

\section{REFERENCES}

Aleotti, P. (2004) A Warning System for RainfallInduced Shallow Failures. Engineering Geology, 73 , pp. 247-265.

American Standard Testing and Material (2000) D2487: Standard Practicefor Classification of Soils for Engineering Purposes (Unified Soil Classification System), 100 Barr Harbor Drive: United States.

Bowles, J.E. (1984) Physical and Geotechnical Properties of Soils, McGraw-Hill Education, New York, USA.

Badan Nasional Penanggulangan Bencana (2014) Indeks Risiko Bencana Indonesia (IRBI) tahun 2013. Direktorat Pengurangan Risiko Bencana, Deputi Bidang Pencegahan dan Kesiapsiagaan BNPB, 332p.

Badan Penanggulangan Bencana Daerah Kabupaten Purworejo (2016) Bencana Tanah Longsor Kabupaten Purworejo dan Rencana Kontijensi; unpublished

Cepeda, J.M., Hoeg, K., Nadim, F. (2010) Landslidetriggering rainfall thresholds: A conceptual framework. Quarterly Journal of Engineering Geology and Hydrogeology, 43(1), pp 69-84.

Cruden, D.M., Varnes, D.J. (1996) Landslide Types and Processes, Transportation Research Board, National Academy of Science.

Dearman, W.R. (1991) Engineering Geological Mapping, Oxford: Butterworth-Heinemann, Ltd.

Geostudio (2012) Computation Laboratory of Civil and Environmental Engineering Department, Faculty of Engineering, Universitas Gadjah Mada.

Guzzetti, F., Peruccacci, S., Rossim M. (2005) Rainfall Thresholds for the Initiation of Landslides in Central and Southern Europe. Risk-Advanced Weather Forecast System to Advise on Risk Events and Management (RISK-AWARE). Meteorology and Atmospheric Physics, 98(3-4), pp. 239-267.

Hardiyatmo, H.C. (2012) Penanganan Tanah Longsor dan Erosi.Edisi pertama. Gadjah Mada University Press, Yogyakarta.

Huang, J., Ju, N.P., Liao, Y.J., Liu, D.D. (2015) Determination of Rainfall Thresholds for Shallow Landslides by a Probabilistic and Empirical Method. Natural Hazard Earth Systems Science, 15, pp. 2715-2723.

Irrigation Department, Public Work Services of Purworejo, (2008-2018), Daftar Laporan Curah Hujan Bagian Bulan Januari-Desember, Purworejo; unpublished.

Karnawati, D. (2005) Bencana Alam Gerakan Massa Tanah di Indonesia dan Upaya Penanggulangannya. Jurusan Teknik Geologi, Fakultas Teknik, Universitas Gadjah Mada, Yogyakarta.

Luca, D.L., Versace, P. (2017) Diversity of Rainfall Thresholds for Early Warning of Hydrogeological Disaster. Advances in Geosciences, 44, pp. 53-60.

Peruccacci, S., Brunetti, M.T., Gariano, S.L.Melillo, M. Rossi, M., Guzzetti, F. (2017) Rainfall Thresholds for the Possible Occurrence in Italy. Geomorphology, 290, pp 39-57.

Rahardjo, W., Sukandarrumidi, Rosidi, H.M.D. (1995) Peta Geologi Lembar Yogyakarta, Jawa. Pusat Penelitian dan Pengembangan Geologi, Bandung.

Reichenbach, P., Cardinali, M., Vita, P.D., Guzetii, F. (1998) Regional Hydrological Thresholds for Landslides and Floods in the Tiber River Basin (Central Italy). Environmental Geology, 35(2-3), pp. 146-159.

Varnes, D.J. (1984) Landslide Hazard Zonation: A Review of Principles and Practice,The UNESCO Press, Paris, 60p.

Varnes, D.J. (1978) Landslides: Analysis and Control, Transportation Research Board Special Report, Issue 176, pp. 11-33; Transportation Research Board. 
RAinfall Thresholds FOR LANDSLIDE Prediction in LOANO SUbDistrict, PURWOREJO District

Widiastutik, R., Buchori, I. (2018) Kajian Risiko Bencana Longsor Kecamatan Loano Kabupaten Pur- worejo. Jurnal Pembangunan Wilayah dan Kota, 14(2), pp.109-122. 